\title{
CRITICAL READING AND WRITING ACROSS THE CURRICULUM ASSISTED BY METACOGNITIVE STRATEGY (BTS) TOWARD STUDENT STUDY CLUB AT UNDIKSHA
}

\author{
I Nyoman Yasa, Imam Suyitno,Yuni Pratiwi
}

Ganesha University of Education, State University of Malang, and State University of Malang

\begin{abstract}
This paper aims at explaining the implementation of RAWAC (Reading and Writing across Curriculum) in teaching essay for college students. Using an action research based integrated with hermeneutic technique, this study was conducted in Kelompok Belajar Mahasiswa (Student Study Club) at Ganesha University of Education, Bali. The result of the study indicates that this model is able to synchronize the excellent aspects of reading-writing and metacognition as those give benefits to the students in terms of strengthening their critical thinking in exploring ideas, their discipline attitude during the process of planning, monitoring, and evaluating concepts, and also strengthening the students' self-regulated learning in writing essay. Implementing RAWAC improve the students' ability in writing essays, especially in exploring ideas, organizing the writing, choosing the diction and enhancing their writing technique.
\end{abstract}

Key words : Critical Reading-Writing across-Curriculum, Metacognitive, KBM (Kelompok Belajar Mahasiswa)

\begin{abstract}
Abstrak: Artikel ini bertujuan untuk mendeskripsikan implementasi RAWAC (Reading-Writing across Curriculum) dalam pengajar esay untuk mahasiswa. Dengan menggunakan penelitian tindakan kelas yang diintegrasikan dengan teknik hermeneutika, penelitian ini dilakukan ke Kelompok Belajar Mahasiswa di Universitas Pendidikan Ganesha, Bali. Hasil penelitian menunjukkan bahwa RAWAC berhasil memadukan aspek yang terdapat di dalam membaca-menulis dan metakognisi karena beberapa keuntungan yang didapat oleh mahasiswa. Keuntungan tersebut adalah meningkatkan proses berpikir kritis dalam mencari ide, peningkatan disiplin mahasiswa dalam proses perencanaan, monitor, evaluasi konsep dan meningkatkan kemampuan belajar mandiri mahasiswa dalam menulis esai. RAWAC berhasil meningkatkan kemampuan mahasiswa dalam menulis esai, khususnya dalam hal eksplorasi ide, organsisasi tulisan, memilih kosakata dan meningkatkan kemampuan teknik menulis.
\end{abstract}

Kata Kunci: membaca-menulis kritis, metakognisi, Kelompok Belajar Mahasiswa $(\mathrm{KBM})$

At the classroom in the University, students have not yet owned the good skills of critical reading and writing. In reading, students haven't caught the content yet and they also haven't 
yet given the critical view toward the content. Meanwhile, their writing skill hasn't been maximal, in the idea, organization, language, diction, and writing technique. Kuta (2008: 7; Isaacson on Defazio, 2010: 35) showed the list of weakness factors which lead to, such as: lack of basic language knowledge, too much spending time in front on TV, lack of strategy knowledge which can be applied, lack of spare time in reading, lack of time for learning at school, and limitation of reading materials on the specific content which hinder students to read and write. Laidlaw (2005:15) stated that the development of writing and student literacy shouldn't be cut down and limited with the wide world literacy as experience of writing literacy surely deliver the significant influence to the students when writing or reading. They will be able to use their own literacy knowledge again.

The rudimentary skills of critical reading and writing haven't arisen at the community of student club at Ganesha University of Education (Undiksha). This community belongs to a student club which develops sciences in a variety of fields which own the similar indulgence and hope. One of the important agenda from the students is to improve their writing skills, both literature writing and non-literature writing.

There are interesting things in the process of writing essays conducted by the students. Firstly, they couldn't focus on starting writing. Secondly, they had doubt about the arisen ideas. Thirdly, they got a difficulty in gaining the ideas to be written down in the essay. Fourthly, their writing is lack of new concepts. Fifthly, they weren't able to regulate themselves to write so much time was spent to accomplish the essay.

The problems in this study club need a solution so their mobility (motivation) to improve themselves through writing is not vanished. One of the activities which can be conducted is teaching critical writing for the students through critical reading assisted by a metacognitive process across the curriculum. The learning will be able to enhance their cognition in writing as the writing skill essentially is laid on the cognitive realm of the students (Defazio, 2010: 34). This paper presents the concept of critical reading and writing across the curriculum; integrating critical reading and writing with a metacognitive learning approach; learning models of critical reading and writing assisted the metacognitive approach towards the students.

\section{METHOD}

This paper is composed based on the result of simple action research which was conducted towards the study club community at Undiksha. Several steps (syntax) conducted by the researcher are (1) delivering the concept to the students in the study club, (2) providing reading texts to the students, (3) asking the students to make response critics towards the texts, (4) asking the students to compose essays based on the problems found in the reading texts, and (5) asking the students to conduct peer review towards their essays. Before conducting the simple action research, the writer explored the critical reading concept, writing across the curriculum, and metacognitive strategy.

In this strategy, there were several steps conducted to the students group learning at Undiksha. Firstly, the students read/learned the humanity journals on the issue as The Benefits of IT and Learning, Woman Violence, Education Practice in Modern Era, etc. In this activity, the students wrote down key words; ambiguous words and sentences, or formulated the questions towards the reading texts and they discussed them in group. It's as 
a learning tool which is able to improve the student group learning of Undiksha through ideas' expression, focus, and the formulated questions.

Secondly, they composed the active response note after reading.

Thirdly, the Undiksha's students reviewed the journals. In this phase, they did not only exploring the topics but also organizing ideas and information which they got by the journals.

Fourthly, the Undiksha's students group learning conducted the peer-review on the contents. In this phase, the students a cross their works each others. They evaluated idea, organization of text, diction, grammar, and style toward their essay. Fifthly, the Undiksha's students group learning revised the essay based on peer reviews.

\section{FINDINGS AND DISCUSSION \\ The Ideas of Critical Reading and Writing Across The Curriculum}

The activities of reading and writing have a close relation. Reading is able to improve the writing skill, and writing can enhance the reading skill. Reading and writing complement each other (Kuta, 2008: xix). Writing is specifically able to assist the students as the readers to own the wide perspective and to solve their reading problems (Bazerman, 1980: 658). Gere (2011: 15) stated that a discipline-based learning in reading and writing can improve the students' mastery towards all learning materials. Without the activities of comprehending and rewriting the materials, the students will face the difficulties in comprehending the main concept (Gere, 2011: 16).

There is an interesting research conducted by Michelle and Susan Miller in the Immunology department of Clinical Laboratory Science (CLS) at Louisville University in 1999. In their research, they apply the programs of reading and writing across the curriculum. There were several steps conducted to the students. Firstly, the students read/learned the immunology journals. In this activity, the students wrote down key words; ambiguous words and sentences, or formulated the questions towards the reading texts and they discussed them in group. Wright (1999: 163) stated that learning journals can be as a learning tool which is able to improve the student learning through ideas' expression, focus, and the formulated questions. Secondly, they composed the active response note after reading. In this phase, the students would be more creative and able to consider psychological and personal aspects on critics which were formulated towards the journal contents. Thirdly, the students reviewed the journals. In this phase, Wright stated that the review assignment as the learning tool, not only exploring the topics but also contributing in organizing ideas and information. Fourthly, the students conducted the peer-review on the contents. Fifthly, the students evaluated the grammar. The result of Critical Reading and Writing Across the Curriculum research conducted by Wright and Miller showed several things. The first is the activity of article analysis on the journal, creating reaction writing, and review as successful strategies to improve the learning. The other results also showed the good appreciation or responses from the students. Generally, the students believed that the reaction writing and article analysis on the journals are the effective learning methods. Peer evaluation was known more moderate and effective and learning/ practice $R A W A C$ built their self confidence and comprehension in reading and writing (Wright, 1999: 164).

\section{The Ideas of Metacognitive Approach in Learning}

Metacognition is simply defined as a thinking activity about the thought or cognition activity about cognition (An, 2013: 632). According to Flavell (on An, 2013: 632; Fahim, 
2014: 80), metacognition refers to a knowledge which emphasizes on the owned cognitive process and products or all things which are produced as the impacts from that cognitive process. Flavell also presented that metacognition refers to activities of monitoring, regulating, and process relation towards data or objects which are thought. Wenden (on An, 2013: 632) applied the term of metacognition in the language learning and differed three types of metacognition, such as: individual knowledge, assignment knowledge, and strategy knowledge. An individual knowledge refers to language convinced the learners as learners, including their cognitive and affective abilities. Assignment knowledge refers to the learners' comprehension towards assignments, like: the purpose and basic objections which are assigned. Strategy knowledge refers to learners' effective strategy used to facilitate and comprehend their learning in line with the assigned objections (Goh on An, 2013: 632). Wenden's idea which applied Metacognition in learning has been followed by most of researchers to research the skills of heeding, reading, and writing. Vandergrift and Goh (on Fahim, 2014: 81) stated that teaching with metacognition is considered as a pedagogy procedure which can enhance the awareness of learning process (heeding, reading, and writing) with enriching the metacognitive knowledge about the students as heeders, readers, and writers; the need of heeding, reading, and writing; and the strategies to heed, read, and write. The metacognitive learning was delivered by Mendelsohn through the series of activities involving planning, monitoring, and evaluating strategy in providing the texts. There are several benefits which can be obtained by the students in the skills of heeding, reading, or writing through metacognition. Firstly, metacognition can give the influences towards both the process and the learning products. Secondly, Metacognitive teaching can assist the students in order to form their self-regulated learning in life (Wenden on Fahim, 2014: 87).

\section{Integrating Critical Reading and Writing Assisted Metacognitive Approach}

The interesting point from the thought of the metacognitive strategy for the writer is three series of activities which are involved, like: planning, monitoring, and evaluating. These three types of make the students owning autonomy which can regulate them in learning. The students who plan their study undergo the learning process; determine their reading texts, choose the preferred topics, compose the schedule of reading-writing activities, create the plan of reading-writing activities, and so on. In monitoring, the students have autonomy to monitor themselves, realize their cognitive thought ability toward the contents, accomplish or enhance themselves if it hasn't been deemed maximal yet, revise the programs which don't support the enhancement of reading-writing learning. In the activity of evaluation strategy, the students can evaluate themselves; their writing deficiencies; their weakness in reading and those points will be able to be improved after they realize (in their thought or cognition) their deficiencies and weakness.

Meanwhile, in $R A W A C$, the elements of planning, monitoring, and evaluating haven't been inside $R A W A C$ yet. Therefore, the metacognitive integration in $R A W A C$ is being as a complement of reading-writing learning management across the curriculum. The model of $R A W A C$ integration and metacognitive strategy are illustrated on figure 1. 


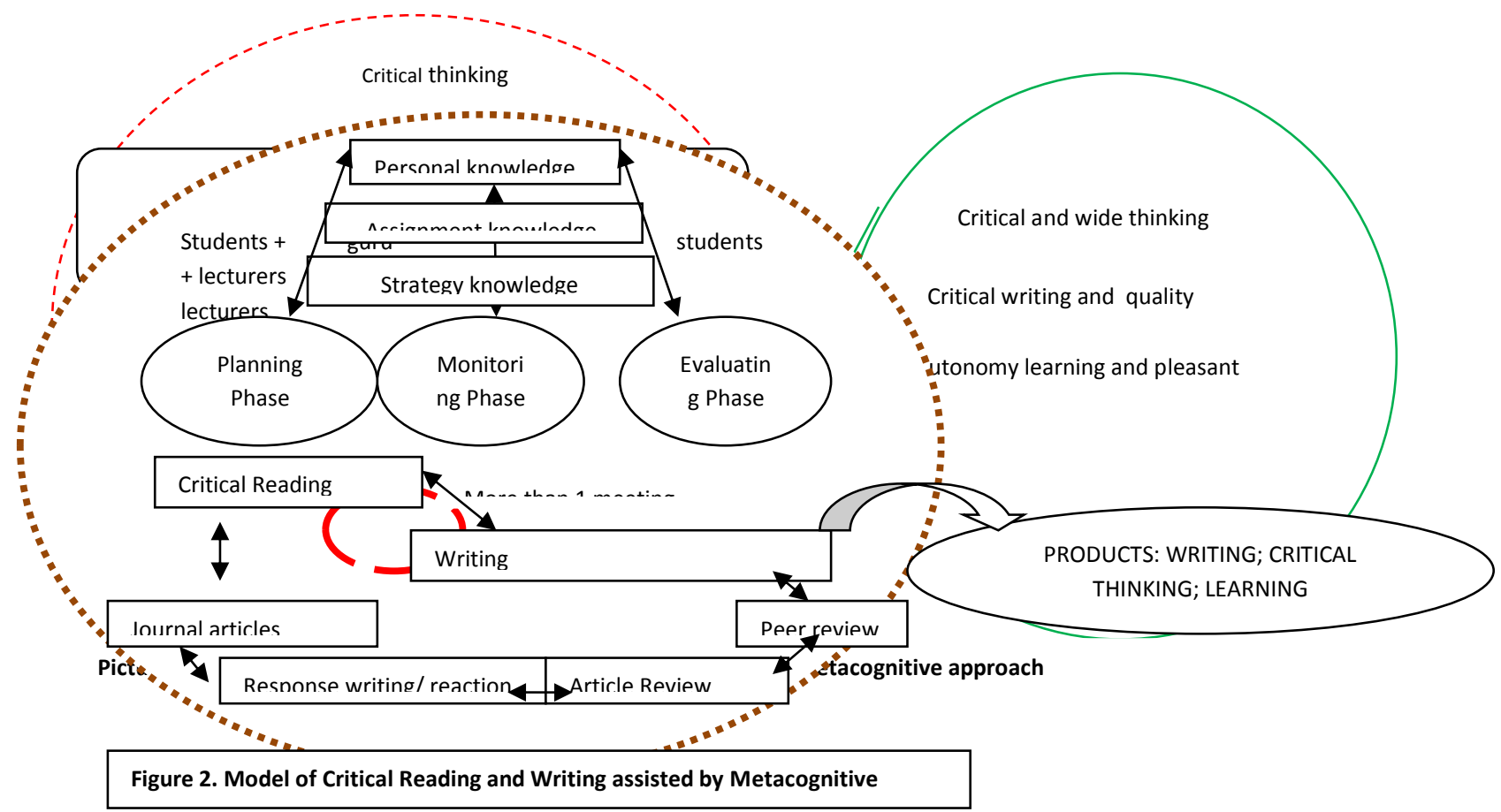

\section{Model of Critical Reading and Writing Learning Assisted By A Metacognitive Approach}

Reading and writing Learning or training across the curriculum combined with this metacognitive strategy is conducted in the community of students' study club at Undiksha. As mentioned in the introduction, the students' study club is a student club which improve themselves in the student activities, including a writing essay activity. The members of the club come from various departments. This program of critical reading and writing across the curriculum assisted metacognitive strategy is appropriately applied in the students' study club with some considerations. Firstly, their writing quality is still only rudimentary. Secondly, the practice of RAWAC hasn't yet applied. Lastly, the students' motivation in writing is high.

The implementation of critical reading and writing learning assisted the metacognitive strategy can be illustrated on the figure 2 below.

The figure 2 above describes that the activities of critical reading and writing across the curriculum assisted by the metacognitive strategy are a process. The learning meetings (training) go on more than one meeting (one semester). The figure 2 shows the collaborative positions between the lecturers and the students. It means that the lecturers always give the guidance to the students to deliver the solution of the problems faced by the students during the planning, monitoring, and evaluating phase. The roles of lecturers as observers and counselors have vital roles in these learning activities.

The party which has the primary role in this learning is the students. The students use their metacognitive consciousness, specifically their consciousness of the personal knowledge, assignment knowledge, or strategy knowledge owned by the students. In this case, the process of realizing the knowledge goes on the planning, monitoring, and evaluating phases. Besides the metacognitive process, the students also undergo the process of choosing the texts, creating the execution schedule: what, who, how it happens on the planning phase. 
Meanwhile, in the monitoring phase, the students always realize how they are understandable, masterful, and critical toward the articles. Besides that, they also realize themselves in writing the responsive essays and reviews. All of the aspects are always monitored so their weaknesses are still triggered to be better, more understandable, and more critical.

In the evaluation phase, the students evaluate themselves metacognitively toward their writing, presentation of idea or concept broadness, and their critic levels. After that, the students conduct the peer-review toward the content, organization, language, diction, and writing technique. The revised writing is collected and evaluated by the lecturers. Based on the results of this simple action research, the students of study club at Undiksha have the good skill in writing essays, especially in exploring their ideas and organizing their writing.

Besides that, critical reading and writing across the curriculum assisted by the metacognitive (BTS) strategy own the important roles in enhancing (1) quality of students' writing, (2) students' critical thinking, (3) students' learning autonomy, (4) the learning convenience and students' learning confidence, and (5) the skill of students' self-regulation learning. Gere (2011: 15) stated that a discipline-based learning in reading and writing can improve the students' mastery towards all learning materials. Without the activities of comprehending and rewriting the materials, the students will face the difficulties in comprehending the main concept (Gere, 2011: 16). Reading before writing can stimulated student's prior knowledge and prior knowledge can help students while writing their idea. Al-Saadat ( 2004: 215) argued that input (knowledge) in reading and writing effected the quality of reading and writing. Iser (on Holub, 1984: 89) explained that there is a pretension and retention dialectical process while reading text. The students constructs meaning toward the humanity journal and than they written their idea in essay as a responds. In this context, the students negotiate meaning in text based on their store of memories: everything that they have ever sensed, experienced, and learned (Robert Fulghum on Vacca, 1999:15).

There are several benefits which can be obtained by the students in the skills of heeding, reading, or writing through metacognition. Firstly, metacognition can give the influences towards both the process and the learning products. Secondly, Metacognitive teaching can assist the students in order to form their self-regulated learning in life. (Wenden on Fahim, 2014: 87). The students use their metacognitive consciousness, specifically their consciousness of the personal knowledge, assignment knowledge, or strategy knowledge owned by the students. In this case, the process of realizing the knowledge goes on the planning, monitoring, and evaluating phases. Besides the metacognitive process, the students also undergo the process of choosing the texts, creating the execution schedule: what, who, how it happens on the planning phase. Meanwhile, in the monitoring phase, the students always realize how they are understandable, masterful, and critical toward the articles. Besides that, they also realize themselves in writing the responsive essays and reviews. All of the aspects are always monitored so their weaknesses are still triggered to be better, more understandable, and more critical.

\section{CONCLUSION AND SUGGESTIONS}

Based on the discussion above, there are several important notes and those important notes are (1) reading and writing across the curriculum are so effective to enhance the students' learning (cognition, affection, and psychomotor), (2) the reading-writing activities can be combined with the metacognitive strategy which functions as the complement of 
students' reading-writing activities management, (3) through, the activities, the writing skill of the students improve. The language (literature) instructors can use the technique of critical reading and writing across the curriculum assisted by the metacognitive strategy in writing study. Besides that, this technique can be used on the other language skills which attempt to enhance the students; critical thinking.

\section{REFERENCES}

Al-Saadat. 2004. Investigating The Relationship of Reading and Writing Abilities in the English Language Program at King Faisal University. Scientific Journal of King Faisal University (Humanities and Management Sciences), Volume 5, No. 1, pp 215-229.

An, X. 2013. Does Metacognitive Instruction Improve Listening Comprehension? Theory and Practice in Language Studies, Vol. 3, No. 4, pp 632-636, April.

Bazeman, C. 1980. A Relationship Between Reading and Writing: The Conversational Model. College English, Vol. 41, No. 6, pp 656-661.

Defazio, J., et al. 2010. Academic Literacy: The Importance and Impact of Writing Across the Curriculum - a Case Study. Journal of the Scholarship of Teaching and Learning, Vol. 10, No. 2, June, pp. 34-47.

Fahim, M. 2014. Maximizing Learners' Metacognitive Awareness in Listening Through Metacognitive Instruction: An Empirical Study. International Journal of Research Studies in Education, Volume 3, Number 3, pp 79-91, July.

Gere, R. A. 2011. Reading and Writing Across The Curriculum A Policy Research Brief Produce by The National Council of Teacher of English. NCRTE, March, p.p 15-18.

Holub, R. C. 1984. Reception Theory A Critical Introduction. London and New York: Methuen.

Laidlaw, L. 2005. Reinventing Curriculum A Complex Perspectives on Literacy and Writing. London: Lawrence Erbaum Associates.

Kuta, K. W. 2008. Reading and Writing to Learn Strategies Across Curriculum. The United States: Teacher Ideas Press.

Wright, M. and S. A. Miller. 1999. Critical Reading and Writing Across the Curriculum in Clinical Laboratory Science. Report and Reviews, Vol. 12, No. 3, May/June, pp. 161-166.

Vacca, R. T. 1999. Content Area Reading Literacy and Learning Across the Curriculum. New York: Longman. 